\title{
The Effect of Oral Dosage with Different Amounts of Linseed Oil on Some Blood Physical and Biochemical Parameters of Iraqi Awassi Lambs
}

\author{
Anwar A. Hussien Alsamaraie and Assi. Prof. Abdullah I. Nuaman \\ Corresponding author: anwararmohandis1@gmail.com, abdullah.nuaman@gmail.com \\ College of Agriculture -Tikrit University
}

\begin{abstract}
This experiment conducted at 8/10/2018 to $10 / 12 / 2018$ by using 16 lambs. The weights of the lambs between (26.64 \pm 0.47$) \mathrm{Kg}$ and the ages between (6-7) mounths, to study the effect of Oral dosage with different amount of linseed oil (LO) on some physical and biochemical blood parameters of Iraqi Awassi lambs. The experiment done by four levels of linseed oil $(0 \% \mathrm{LO})(0.25 \% \mathrm{LO}),(0.5 \% \mathrm{LO}),(0.8 \% \mathrm{LO})$ mllkg Dry matter and the hay was freely introduced. and by four treatments each of them consists of 4 lambs. The results showed high significant differences $(\mathrm{P} \leq 0.01)$ in the fourth treatment compared with the first treatment in the concentration of hemoglobin, Hematocrit, number of Red Blood Cells, number of white blood cells, Mean Corpuscular Volume and Mean Corpuscular Hemoglobin ( $9.81 \mathrm{dl} / \mathrm{mg}, 36.84 \%, 6.06 \times 10^{6}, \times 4.29 \times 10^{3}$ and $53.71 \mathrm{FI}$ ) respectively. while the results showed a significant increase $(\mathrm{P} \leq 0.05)$ in Mean Corpuscular Hemoglobin. The results of biochemical tests showed at the beginning of the experiment that there were no significant differences between the treatments in the concentration of triglycerides, but there was highly significant $(\mathrm{P} \leq 0.01)$ decrement at the middle and end of experiment. As for the total blood protein, although there was no significant difference in its concentration at the end of the experiment, it was noted that there was a high significant differences at $(\mathrm{P} \leq 0.01)$ in the concentration of albumin and globulin middle and end of the experiment.
\end{abstract}

Keywords: Animal feed, Awassi lambs, linseed oil

\section{Introduction}

Sheep are considered as a one of Sources of animal protein production in Iraq, also they are contributes in the production of red meat and milk and has an annual contribution of 30.93 and 602 thousand tons, respectively (FAO,2000), The Awassi sheep in Iraq constitute the largest proportion of sheep, reaching about 3 million in 2002 (Talimat et al., 2002), This breed is characterized by its ability to produce in harsh environmental conditions and adapt to live in dry farming areas and deserts and spread in Nineveh and the central region of Iraq (Habiti , 2005).Linseed oil is one of the most nutritional important plant oils for both humans and animals (Rubilar et al., 2010) .It has gained this importance as an essential ingredient in the production of oil rich in fatty acids (medical news today, 2018), the seeds are rich in its content of omega-3 fatty acid (Alpha- linolenic acid) and short-chain polyunsaturated fatty acids (kajla and Sharma, 2015). This experiment was conducted to investigate the effect of oral dosage with Linseed oil on some physiological traits and blood biochemical parameters.

\section{Materials and Methods}

This study was conducted in the animal field of the Department of Animal Production at the College of Agriculture - University of Tikrit for 63 days from $8 / 10 / 2018$ to $10 / 12 / 2018$. The lambs were fed for 14 days on the basic diet (Table 2), and were considered a preliminary period for the purpose of adaptation, then the lambs were weighed for two consecutive days using the electronic field balance, with primary weight $(26.64 \mathrm{~kg})$. All the lambs divided randomly by the weight into four group, and were fed on one diet with a low protein level of $12.3 \%$ (Table 1).

Table 1. Experiment diet ingredients and percentage of use.

\begin{tabular}{lcccc}
\hline Feeding Material & T1 & T2 & T3 & T4 \\
& LO \%0 & LO \%0.25 & LO \%0.5 & LO \%0.8 \\
\hline Barley & 60 & 60 & 60 & 60 \\
Wheat Bran & 35 & 35 & 35 & 35 \\
Corn & 3 & 3 & 3 & 3 \\
Premix and Salt & 2 & 2 & 2 & 2 \\
Linseed oil & 0 & 2.5 & 5 & 8 \\
\hline
\end{tabular}

The diet was provided with a nutrition level of $2 \%$ of body weight and doses of linseed oil according to the four experimental treatments $0,0.25,0.5$, and $0.8 \%$ $\mathrm{ml} / \mathrm{kg}$ of dry matter (lambs were placed in individual cages in a semi-enclosed barn and provided with food Plates and water Pails). Lambs were fed a standard 
diet of feedstuffs available in local markets (wheat bran, black barley and yellow corn) (Table 2). The diet was provided on two meals a day at 8 am and $6 \mathrm{pm}$ and the wheat straw was provided to animals freely. All animals underwent a veterinary program of vaccination and dosage.

\section{Blood samples}

The animals were fasted before drawing blood for 12 hours, In The beginning, middle and end of the experiment and $10 \mathrm{mls}$ of blood were collected from the jugular vein by a sterile syringe and put $2 \mathrm{ml}$ in sterile plastic test tubes containing anticoagulant (EDTA) For physical blood tests, while the other part of the blood was placed in clean, sterile centrifuge glass gel tubes that separated the serum from the other components of the blood for an hour at room temperature, the serum was transferred to the centrifuge plastic tubes and stored under temperature $-18^{\circ} \mathrm{C}$ in the freezer until the biochemical tests were performed.

Table 2. Chemical composition of the experiment diet

\begin{tabular}{lcccc}
\hline Substance & Barley & Wheat & Corn & Total percentage \\
\hline Dry matter & 55.71 & 31.65 & 2.68 & 90.04 \\
Crude protein & 6.43 & 5.55 & 0.27 & 12.25 \\
Ether extract & 0.85 & 1.42 & 0.13 & 2.4 \\
Crude fiber & 3.90 & 3.72 & 0.06 & 7.68 \\
Ash & 2.29 & 1.75 & 0.07 & 4.11 \\
Soluble carbohydrate & 42.23 & 19.21 & 2.14 & 63.58 \\
\hline
\end{tabular}

\section{Physical blood tests}

Physical blood tests were performed as follows: Hemoglobin concentration was measured by Drabkin and Austin method (1935) and the percentage of packet cell volume of Red Blood Cells was measured by Hematocrit and the number of Red Blood Cells using _hemocytometer (Hughes et al., 2004). White blood cells were calculated using a slice count.

\section{Biochemical tests for serum}

The level of serum triglycerides in the enzymatic method was determined by using the work kit manufactured by the French company biolabo (Fossati and Prencipe, 1982), then reading the absorbance of samples and the standard solution at $500 \mathrm{~nm}$ wavelength. The Baylorite method was used to estimate the total protein and albumin in the serum, by using of a green bromocresol (biolabo ready solutions kit), then reading the absorbance of samples and the standard solution at $630 \mathrm{~nm}$ wavelength. Serum globulin concentration was determined by the following equation:

Globulin amount $(\mathrm{mg} / \mathrm{dl})=$ total protein concentration $(\mathrm{mg} / \mathrm{dl})$ - albumin concentration ( $\mathrm{mg} / \mathrm{dl}$ ) Bishop et al. (2000).

\section{Statistical Analysis}

The statistical analysis was carried out using the complete random one-way design, In order to test the significance of the differences between the coefficients, the Duncan polynomial test was used, SAS (2001) was used to analyze data according to the following mathematical model:

$Y i j=\mu+T i+e i j$

\section{Results and Discussion}

Effect of oral dosage with Linseed oil on physical blood characteristics:

\section{1: Concentration of hemoglobin:}

The effect of the treatment with linseed oil was highly significant $(\mathrm{P} \leq 0.01)$ and Table (4) show that the hemoglobin concentration in the fourth treatment $9.81 \pm 0.01 \mathrm{gm} / \mathrm{dl}$ was highly significant $(\mathrm{P} \leq 0.01)$ compared with other treatment, while the first treatment was the lowest treatment $\quad(9.30$ $\pm 0.03 \mathrm{gm} / \mathrm{dl}$ ) may be due to a difference that occur in the number of Red Blood Cell.

\section{2: Hematocrit}

The Hematocrit was highly significant $(\mathrm{P} \leq 0.01)$ affected by Linseed oil treatment, From Table (4) the fourth treatment was highly significant (36.84 \pm $0.03 \%)$ at $\mathrm{P}$ value $\leq 0.01$ compared with the other treatments and the control treatment was lowest $(35.23 \pm 0.05 \%)$, and this result may be attributed to the difference in the number of Red Blood Cells.

\section{3: The total number of Red Blood Cells}

The results in Table (4) show a highly significant effect $(\mathrm{P} \leq 0.01)$ on the total number of Red Blood Cells, the fourth treatment was morally higher $6.06 \pm$ $0.07 \times 10^{6}$ at a $P$ value $\leq 0.01$, while the first treatment was the lowest $\left(5.37 \pm 0.23 \times 10^{6}\right)$. Knowing that these numbers are within the normal range of number of Red Blood Cells.

\section{4: Total number of white blood cells}

Table (4) shows that the total number of white blood cells was significantly affected $(\mathrm{P} \leq 0.01)$, This is due to the healthy condition of the lambs and their number is within the normal range of Iraqi sheep or This may be due to the presence of omega-3 in Linseed oil, which contributes to reinforcement and strengthen the immunity by increasing the cells swallowing foreign bodies on the body. 
Table 4. Effect of oral dosage with Linseed oil on physical blood characteristics (mean \pm Standard error) in experiment parameters.

\begin{tabular}{|c|c|c|c|c|c|}
\hline \multirow[b]{2}{*}{ characteristics } & \multicolumn{4}{|c|}{ Treatments } & \multirow{2}{*}{$\begin{array}{c}\text { Significantly } \\
\text { level }\end{array}$} \\
\hline & $\begin{array}{c}\text { T1 } \\
\text { LO 0\% }\end{array}$ & $\begin{array}{c}\text { T2 } \\
\text { LO } 0.25 \%\end{array}$ & $\begin{array}{c}\text { T3 } \\
\text { LO } 0.5 \%\end{array}$ & $\begin{array}{c}\text { T4 } \\
\text { LO0.8\% }\end{array}$ & \\
\hline Hemoglobin HGB $(\mathrm{gm} / \mathrm{dl})$ & $9.30 \pm 0.03^{\mathrm{d}}$ & $9.51 \pm 0.01^{\mathrm{c}}$ & $\begin{array}{l}9.64 \pm \\
0.02^{\mathrm{b}}\end{array}$ & $\begin{array}{c}9.81 \pm \\
0.01^{\mathrm{a}}\end{array}$ & $* *$ \\
\hline Hematocrit HCT \% & $\begin{array}{c}35.23 \pm \\
0.05^{\mathrm{d}}\end{array}$ & $35.23 \pm 0.05^{\mathrm{d}}$ & $\begin{array}{c}36.45 \pm \\
0.08^{\mathrm{b}}\end{array}$ & $\begin{array}{c}36.84 \\
\pm 0.03^{\mathrm{a}}\end{array}$ & $* *$ \\
\hline Red Blood Cell RBC X $10^{6}$ & $5.37 \pm 0.23^{c}$ & $5.74 \pm 0.01^{\mathrm{b}}$ & $\begin{array}{c}5.85 \pm \\
0.03^{\mathrm{b}}\end{array}$ & $\begin{array}{c}6.06 \pm \\
0.07^{\mathrm{a}}\end{array}$ & $* *$ \\
\hline White Blood Cells WBC X10 3 & $5.59 \pm 0.13^{\mathrm{a}}$ & $4.87 \pm 0.10^{\mathrm{b}}$ & $\begin{array}{c}4.57 \pm \\
0.06^{\mathrm{c}}\end{array}$ & $\begin{array}{c}4.29 \pm \\
0.04^{\mathrm{c}}\end{array}$ & $* *$ \\
\hline $\begin{array}{l}\text { Mean Corpuscular Volume } \\
\text { MCV FI }\end{array}$ & $54.25 \pm 0.03^{\mathrm{a}}$ & $54.09 \pm 0.01^{\mathrm{b}}$ & $\begin{array}{l}53.92 \\
\pm 0.10^{\mathrm{b}}\end{array}$ & $\begin{array}{l}53.71 \\
\pm 0.14^{\mathrm{c}}\end{array}$ & $* *$ \\
\hline $\begin{array}{l}\text { Mean Corpuscular } \\
\text { Hemoglobin MCH Pg }\end{array}$ & $16.61 \pm 0.03^{\mathrm{a}}$ & $16.45 \pm 0.01^{\mathrm{b}}$ & $\begin{array}{r}16.39 \\
\pm 0.02^{\mathrm{b}}\end{array}$ & $\begin{array}{l}16.20 \\
\pm 0.09^{c}\end{array}$ & $* *$ \\
\hline $\begin{array}{l}\text { Mean Corpuscular } \\
\text { Hemoglobin Concentration } \\
\text { MCHC gm/dl }\end{array}$ & $30.38 \pm 0.01^{\mathrm{a}}$ & $30.32 \pm 0.01^{\mathrm{b}}$ & $\begin{array}{l}30.32 \\
\pm 0.02^{b}\end{array}$ & $\begin{array}{l}30.32 \\
\pm 0.01^{\mathrm{b}}\end{array}$ & $*$ \\
\hline
\end{tabular}

Averages with different characters within a row are significantly different* $(\mathrm{P} \leq 0.05), * *(\mathrm{P} \leq 0.01)$.

\section{5: Mean Corpuscular Volume}

The Mean Corpuscular Volume was highly affected by oral dosage with linseed oil $(\mathrm{P} \leq 0.01)$ As observed in Table (4). Mean Corpuscular Volume is inversely proportional with the number of Red Blood Cells although it was in the normal range.

\section{6:Mean Corpuscular Hemoglobin}

Table (4) shows that the rate of Mean Corpuscular Hemoglobin was significantly $(\mathrm{P} \leq 0.01)$ affected by the ratios of oral dosage linseed oil as it decreased in the three treatments compared to the control treatment where the Mean Corpuscular Hemoglobin in the fourth treatment $(16.20 \pm 0.09 \mathrm{Pg})$ and in the third $(16.39 \pm 0.02 \mathrm{Pg})$, In the second it was $16.45 \pm$ $0.01 \mathrm{Pg}$ compared to the control treatment (16.61 \pm $0.03 \mathrm{Pg}$ ). This may be caused by a high significant decrease $(P \leq 0.01)$ in the number of Red Blood Cells with which the Mean Corpuscular Hemoglobin is directly proportional.

\section{7:Mean Corpuscular Hemoglobin Concentration}

Table (4) showed a significant effect $(\mathrm{P} \leq 0.05)$ Mean Corpuscular Hemoglobin Concentration. The results showed that the concentration in the second, third and fourth treatment was significantly less $(\mathrm{P} \leq 0.05)(30.32 \pm 0.01,30.32 \pm 0.02$ and $30.32 \pm 0.01$ $\mathrm{gm} / \mathrm{dl}$ ), respectively compared to with control treatment $(30.38 \pm 0.01 \mathrm{gm} / \mathrm{dl})$ This may be because the number of Red Blood Cells is inversely proportional to the Mean Corpuscular Hemoglobin Concentration.

Effect of oral dosage with Linseed oil on biochemical blood characteristics:

\section{1: triglyceride concentration}

In Table (5), no significant differences were observed in the first draw (beginning of the experiment), In the Middle of the experiment there was a significant decrease $(\mathrm{P} \leq 0.01)$ as a result of oral dosage with Linseed oil in the second, third and fourth treatments compared with the first (control). The highest concentration was the fourth treatment (67.37 $\pm 0.30 \mathrm{mg} / \mathrm{dl})$. The decrease continued to the end of the experiment and was highly significant $(\mathrm{P} \leq 0.01)$ in the second, third and fourth treatments compared with the first (control). The fourth treatment was the highest $63.03 \pm 0.20 \mathrm{mg} / \mathrm{dl}$. The reason for this decrease is Maybe because the presence of a high percentage of omega-3 in linseed oil, which leads to a decrease in the concentration of triglycerides in the blood plasma, through the involvement of omega - 3 in reducing or curbing the secretion and manufacture of very low - density lipoprotein (VLDL) of liver cells.Omega-3 also converts low-density lipoproteins into intermediate-density lipoproteins and then to lowdensity lipoproteins, Omega-3 also play an effective role in regulating sensitive genes that control body fat balance by reducing the accumulation and secretion of very low-density lipoproteins and thus reducing triglycerides by reducing the effectiveness of the steroid-ester receptors for protein-related elements, Which is the key to controlling the process of manufacturing fat, as well as omega-3 plays an important role in increasing the process of oxidation of fat in the mitochondria and thus reduce the concentration of triglycerides in the blood plasma Ishak and Mahmood (2014). 
Table 5. Effect of oral dosage with Linseed oil on the concentration of triglycerides (mg/dl) (mean \pm Standard error) in experiment Treatments.

\begin{tabular}{|c|c|c|c|c|c|}
\hline \multirow{2}{*}{$\begin{array}{l}\text { Time to } \\
\text { draw blood }\end{array}$} & \multicolumn{4}{|c|}{ Treatments } & \multirow[b]{2}{*}{$\begin{array}{c}\text { Significantly } \\
\text { level }\end{array}$} \\
\hline & $\begin{array}{c}\text { T1 } \\
\text { LO } 0 \%\end{array}$ & $\begin{array}{c}\text { T2 } \\
\text { LO } 0.25 \%\end{array}$ & $\begin{array}{c}\text { T3 } \\
\text { LO } 0.5 \%\end{array}$ & $\begin{array}{c}\text { T4 } \\
\text { LO0.8\% }\end{array}$ & \\
\hline $\begin{array}{l}\text { Beginning of the } \\
\text { experiment }\end{array}$ & $\begin{array}{c}73.23 \pm \\
0.24^{\mathrm{a}}\end{array}$ & $72.94 \pm 0.22^{a}$ & $\begin{array}{c}72.20 \pm 0.72 \\
\text { a }\end{array}$ & $\begin{array}{c}72.74 \pm \\
0.25^{\mathrm{a}}\end{array}$ & NS \\
\hline $\begin{array}{l}\text { Middle of the } \\
\text { experiment }\end{array}$ & $\begin{array}{c}72.32 \pm \\
0.15^{\mathrm{a}}\end{array}$ & $70.50 \pm 0.03^{b}$ & $\begin{array}{c}68.70 \pm \\
0.47^{\mathrm{C}}\end{array}$ & $\begin{array}{c}67.37 \pm \\
0.30^{\mathrm{d}}\end{array}$ & $* *$ \\
\hline End of the experiment & $\begin{array}{c}71.03 \pm \\
0.32^{\mathrm{a}}\end{array}$ & $68.33 \pm 0.04^{b}$ & $\underset{\mathrm{C}}{65.49 \pm 0.15}$ & $\begin{array}{c}63.03 \pm \\
0.20^{\mathrm{d}}\end{array}$ & $* *$ \\
\hline
\end{tabular}

NS no significant.

Averages with different characters within a row are significantly different** $(\mathrm{P} \leq 0.01)$.

Blood protein concentration:

1: Total protein

Table (6) shows that the total protein concentration at the beginning of the experiment had no significant differences between treatments In the Middle of the experiment, the second, third and fourth treatments were significantly affected $(\mathrm{P} \leq 0.01)$ in total protein concentration $(7.20 \pm 0.03,7.36 \pm 0.02$ and $7.17 \pm 0.09) \mathrm{mg} / \mathrm{dl}$, respectively compared with control treatment $(7.66 \pm 0.09) \mathrm{mg}$. / dl. The decrease in the total protein concentration in the blood plasma may be due to the low protein content in the diet eaten by lambs, In addition to low protein content in flaxseed oil.

Table 6. Effect of oral dosage with Linseed oil on the concentration of Total protein $(\mathrm{mg} / \mathrm{dl})$ (mean \pm Standard error) in experiment Treatments.

\begin{tabular}{|c|c|c|c|c|c|}
\hline \multirow[b]{2}{*}{ Time to draw blood } & \multicolumn{4}{|c|}{ Treatments } & \multirow{2}{*}{$\begin{array}{c}\text { Significantly } \\
\text { level }\end{array}$} \\
\hline & $\begin{array}{c}\text { T1 } \\
\text { LO } 0 \%\end{array}$ & $\begin{array}{c}\text { T2 } \\
\text { LO0.25\% }\end{array}$ & $\begin{array}{c}\text { T3 } \\
\text { LO } 0.5 \%\end{array}$ & $\begin{array}{c}\text { T4 } \\
\text { LO0.8\% }\end{array}$ & \\
\hline $\begin{array}{l}\text { Beginning of the } \\
\text { experiment }\end{array}$ & $\begin{array}{c}7.10 \pm 0.07 \\
\mathrm{a}\end{array}$ & $7.92 \pm 0.08^{a}$ & $7.95 \pm 0.05^{\mathrm{a}}$ & $\begin{array}{c}8.04 \pm \underset{a}{0.09} \\
0.09\end{array}$ & $* *$ \\
\hline Middle of the experiment & $7.66 \pm 0.09$ & $7.20 \pm 0.03^{b}$ & $7.36 \pm 0.02^{b}$ & $7.17 \pm \frac{\mathrm{b}}{\mathrm{b}} 0.09$ & $* *$ \\
\hline End of the experiment & $7.34 \pm \underset{\mathrm{a}}{0.10}$ & $6.35 \pm 0.05^{c}$ & $6.69 \pm 0.07^{b}$ & $\begin{array}{l}6.15 \pm \\
0.02^{\mathrm{d}}\end{array}$ & NS \\
\hline
\end{tabular}

NS no significant.

Averages with different characters within a row are significantly different** $(\mathrm{P} \leq 0.01)$.

\section{2:The albumin}

The results of the statistical analysis shown in Table (7) show that the albumin concentration was significantly lower $(\mathrm{P} \leq 0.01)$ at the beginning of the experiment for the second, third and fourth treatment as it was $5.66 \pm 0.01,5.76 \pm 0.07$ and $6.00 \pm 0.04 \mathrm{mg}$ / dl, respectively compared with control treatment
$6.34 \pm 0.03 \mathrm{mg} / \mathrm{dl}$. In the middle of the experiment, the second, third and fourth treatments were significantly affected at $(\mathrm{P} \leq 0.01)$ compared with the control treatment and this effect continued to the end of the experiment. This decrease is due to the lack of protein in the diet and in linseed oil, That's where the albumin is the largest proportion of total protein.

Table 7. Effect of oral dosage with Linseed oil on the concentration of albumin $(\mathrm{mg} / \mathrm{dl})$ (mean \pm Standard error) in experiment Treatments.

\begin{tabular}{|c|c|c|c|c|c|}
\hline \multirow[b]{2}{*}{ Time to draw blood } & \multicolumn{4}{|c|}{ Treatments } & \multirow[b]{2}{*}{$\begin{array}{c}\text { Significantly } \\
\text { level }\end{array}$} \\
\hline & $\begin{array}{c}\text { T1 } \\
\text { LO } 0 \%\end{array}$ & $\begin{array}{c}\mathrm{T} 2 \\
\mathrm{LO} 0.25 \%\end{array}$ & $\begin{array}{c}\text { T3 } \\
\text { LO } 0.5 \%\end{array}$ & $\begin{array}{c}\text { T4 } \\
\text { LO0.8\% }\end{array}$ & \\
\hline $\begin{array}{l}\text { Beginning of the } \\
\text { experiment }\end{array}$ & $6.34 \pm 0.03^{a}$ & $5.66 \pm 0.01^{\mathrm{c}}$ & $5.76 \pm 0.07^{\mathrm{c}}$ & $6.00 \pm 0.04^{\mathrm{b}}$ & $* *$ \\
\hline $\begin{array}{l}\text { Middle of the } \\
\text { experiment }\end{array}$ & $6.07 \pm 0.06^{\mathrm{a}}$ & $5.23 \pm \underset{b}{0.06}$ & $5.34 \pm 0.08^{b}$ & $5.36 \pm 0.05^{b}$ & $* *$ \\
\hline End of the experiment & $5.81 \pm 0.08^{a}$ & $4.65 \pm 0.10$ & $4.85 \pm 0.09^{b}$ & $4.60 \pm 0.06^{b}$ & $* *$ \\
\hline
\end{tabular}

Averages with different characters within a row are significantly different** $(\mathrm{P} \leq 0.01)$. 


\section{3: Globulin}

Globulin concentration decreased with the progress of the experiment. A significant difference $(\mathrm{P} \leq 0.01)$ was observed in the second, third and fourth treatment compared with the first (control). There was no significant difference between the first, second and fourth treatments, while the third treatment was significantly outperformed $(1.84 \pm 0.05 \mathrm{mg} / \mathrm{dl})$ (Table 8).Globulin concentration decreased with the progress of the experiment. During the first draw a significant difference $(\mathrm{P} \leq 0.01)$ was observed in the second, third and fourth treatment compared with the first treatment (control). When comparing the results from the beginning to the end of the experiment within one treatment, we find that the second, third and fourth treatment were significantly affected $(\mathrm{P} \leq 0.01)$ in the Middle of the experiment compared to the beginning, while the first treatment was not affected, The significant effect $(\mathrm{P} \leq 0.01)$ in the second, third and fourth treatment continued to the end of the experiment compared with the beginning of the experiment while the first treatment did not change significantly at the end of the experiment compared with the beginning of the experiment.

Table 8. Effect of oral dosage with Linseed oil on the concentration of Globulin $(\mathrm{mg} / \mathrm{dl})$ (mean \pm Standard error) in experiment Treatments.

\begin{tabular}{|c|c|c|c|c|c|}
\hline \multirow[b]{2}{*}{ Time to draw blood } & \multicolumn{4}{|c|}{ Treatments } & \multirow{2}{*}{$\begin{array}{c}\text { Significantly } \\
\text { level }\end{array}$} \\
\hline & $\begin{array}{c}\text { T1 } \\
\text { LO0\% } \\
\end{array}$ & $\begin{array}{c}\text { T2 } \\
\text { LO0.25\% } \\
\end{array}$ & $\begin{array}{c}\text { T3 } \\
\text { LO0.5\% } \\
\end{array}$ & $\begin{array}{c}\text { T4 } \\
\text { LO0.8\% } \\
\end{array}$ & \\
\hline $\begin{array}{l}\text { Beginning of the } \\
\text { experiment }\end{array}$ & $1.66 \pm 0.05^{\mathrm{b}}$ & $2.26 \pm 0.04^{\mathrm{a}}$ & $\begin{array}{c}2.19 \pm 0.07 \\
\mathrm{a}\end{array}$ & $2.03 \pm 0.11^{\mathrm{a}}$ & $*$ \\
\hline $\begin{array}{l}\text { Middle of the } \\
\text { experiment }\end{array}$ & $1.60 \pm 0.05^{b}$ & $1.97 \pm 0.09^{\mathrm{a}}$ & $\frac{2.03 \pm 0.06}{\mathrm{a}}$ & $\begin{array}{l}1.81 \pm \\
0.10^{\mathrm{ab}}\end{array}$ & $* *$ \\
\hline End of the experiment & $1.53 \pm 0.04^{b}$ & $1.70 \pm 0.20^{\mathrm{ab}}$ & $1.84 \underset{\mathrm{a}}{ \pm 0.05}$ & $1.55 \pm \frac{\mathrm{b}}{\mathrm{b}} 0.08$ & $* *$ \\
\hline
\end{tabular}

Averages with different characters within a row are significantly different* $(\mathrm{P} \leq 0.05), * *(\mathrm{P} \leq 0.01)$.

\section{References}

Bishop, M. L. ; Dube-Engerlik, J. L. ; and Fody, E. P. (2000). Clinical Chimistr: Principles, Correlation's, Procedures. 4th ed. Philadelphia. Pp. 405-416.

Drabkin, D. L. and Austin, J. H. (1935). J. Biol. Chem. 112-151.

FAO.2000 . Production yearbook. VI-Livestock numbers and production. Food and Agricultural Organization of the United Nations, Rome. Vol. 50.

flaxseed?" "www.medicalnewstoday.com, Retrieved 9-9-2018. Edited.

Fossati ,P. and Prencipe, L .(1982). Serum Triglycerides determination colorimtrically with an enzyme that produces hydrogen peroxides. Clin Chem.,28:2077-2085.

Habiti, Aref Qasim Hassan. 2005. The relationship between the composition of the udder with milk production and some of its components in Awassi sheep. Ph.D. thesis - University of Mosul - College of Agriculture and Forestry.
Hughes, N. C. ; Wickramasinghe, S. N. and Hatton, C. (2004). Lecture notes on Hematology. Seventh edition. Blackwell Publishing. London.

Ishak, M. A., \& Mahmood, F. A. (2014). Effect of using different levels of flaxseed on physiological performance in Awassi Turkish ewes. Al-Anbar Journal of Veterinary Sciences, 7(1), 44-55.

Kajla P, Sharma A, Sood DA. Flaxseed. 2015. a potential functional food source, Journal of Food Science and Technology. 52(4):1857-1871.

Rubilar M, Gutiérrez C, Verdugo M, Shene C, Sineiro J.(2010). Flaxseed as a source of functional ingredients. Journal of Soil Science and Plant Nutrition. 2010; 10:373-377.

SAS, Statistical Analysis System .(2001). / stat Users Guide for Personal Computers . Release . 6:12 . SAS Institute Inc.,Cary , N.C., U.S.A.

Talimat, Farhan Munir and Al-Khatib, Rifaat and Mazen, Safia and Al-Hark, Ismail.(2002). Systems and Economics of Awassi Sheep Production for Breeders in Syria, Arab Center for the Studies of Arid Zones and Arid Lands, Damascus, Syria. P. 81. 


\section{تأثير التجريع بزيت بذور الكتان في بعض صفات الدم الفيزياوية والكيموحيوية في الحملان العواسية العراقية

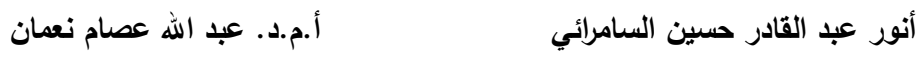 \\ abdullah.nuaman@gmail.com , anwararmohandis1@gmail.com}

$$
\text { كلية الزراعة جامعة تكريت }
$$

أجريت هذه الدراسة في الفترة من 2018/10/8 حتى 2018/12/10 باستخدام 16 حملا عواسيا جميعها من الذكور ، وكانت أوزان الحملان

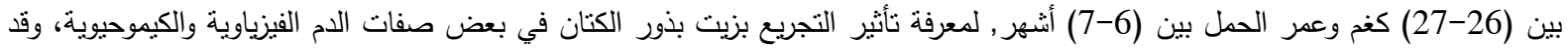

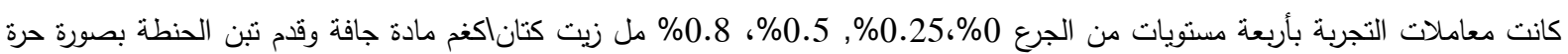

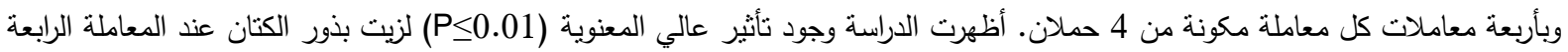

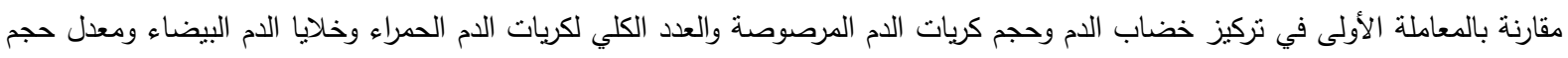

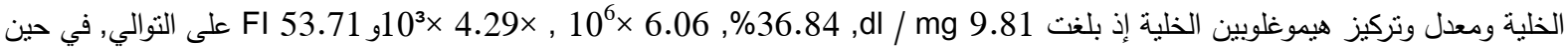

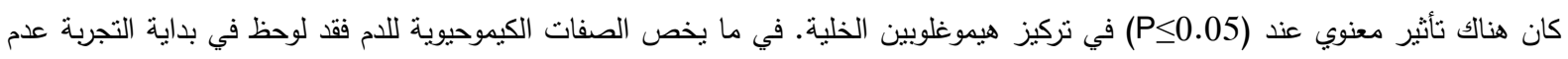

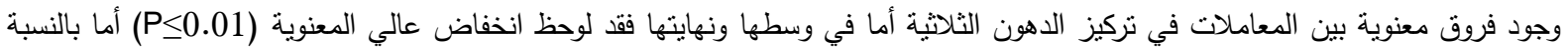

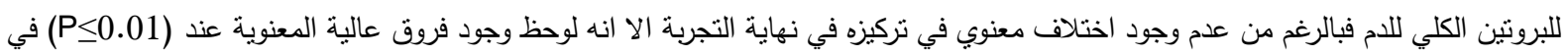
تركيز الألبومين والغلوبيولين وسط ونهاية التجربة.

الكلمات المفتاحية: تغذية حيوان، أغنام عواسية، زيت بذور الكتان. 